2020 (117-118): 267-271.

(C) A szerzö(k) 2020

replika.hu/replika/117-118

\title{
Bartha Dıána
}

\section{A cselekvés és a tiszta tudomány összeegyeztethetôsége}

fáber Ágoston [2018]: Pıerre Bourdıeu: Elmélet és polıtıla. Budapest: Mapuilág Hıadó [Társadalomelméletı múhely sorozat]

\begin{abstract}
Absztrakt: Fáber Ágoston könyve az első magyar nyelven írt átfogó mű Pierre Bourdieu munkásságáról. A kötet végigköveti a francia szociológus tudományos pályafutását, bemutatva legfontosabb elméleteit, kidolgozott módszertani megközelítéseit. Fáber írásának célja áttekinteni a bourdieu-i munkásság kritikus pontjait, állást foglalva a „két Bourdieu”-ről szóló vitában. A hiánypótló könyv következetesen mutatja be Pierre Bourdieu munkásságának fejlődését, összeegyeztetve a francia szociológus akadémiai kutatásait a politikai aktivizmusával.
\end{abstract}

Kulcsszavak: habitus, mezőelmélet, ágens, gyakorlat-elmélet, aktivizmus 
Hogyan termelődik a tudományos tudás? Kinek termelődik a tudományos tudás? Hogyan működik a társadalom, mi és miért tartja fenn a már meglévő viszonyokat? Mi a szerepe a tudománynak e viszonyok tekintetében? A fenntartásuk, lerombolásuk, vagy csupán a létezésükre történő rámutatás?

Fáber Ágoston Magyarországon elsőként írt összefoglaló művet Pierre Bourdieu munkásságáról. A kötet nem áll meg a világhírü - Közép- és Kelet-Európában szinte megkerülhetetlen - szerző tudományos szférában történő előrehaladásának bemutatásánál: Fáber a francia szociológust gyötrő kulcskérdések sorát mutatja be. E kérdések - amelyek vélhetőleg Bourdieu személyes élettörténetéből fakadnak - megtermékenyítették a szerzőt, meghatározták a tudományos érdeklődését és mintegy központi magként koordinálták, irányították az általa bejárt szakmai pályát is. A francia szociológus egy dél-franciaországi aprócska településről tornázta fel magát a francia akadémiai élet csúcsára, valamint élete utolsó szakaszában a közéletben vállalt tevékenységével a baloldali társadalmi mozgalmak kulcsfigurájává, motorjává vált.

2018-ban megjelent könyvében Fáber fejezetről fejezetre követi végig a világhírü francia tudós elméletének kibontakozását, ütköztetve a felmerülő kritikákkal. Az első fejezetében rögtön az elméletet érintő leggyakrabban hangoztatott vádat bontja ki, a francia szociológus ugyanis az általa kidolgozott habitus- és mezőelmélettel, valamint a cselekvők, ágensek korlátozott reflexív képességét hangsúlyozó nézetével kivívta, hogy munkáját rendszerint a determinizmus vádjával illessék. A bourdieu-i elmélet a társadalmi kényszerek által kijelölt utakat és viszonyokat, valamint a cselekvő egyének számára észrevehetetlen uralmi rendszerek újratermelödését írja le. Az elmélet központi eleme az általa ágensként megnevezett cselekvők társadalmi viszonyokkal szembeni tehetetlensége. Az uralmi rendszerek és fennálló hierarchiák újratermelődésének okát elsősorban abban látja, hogy az ágensek nem ismerik fel az őket elnyomó struktúrákat. A kidolgozott elmélet látszólagos ellentmondásban áll a kutató kései munkásságát meghatározó közéleti tevékenységével, amellyel az ágensek mozgósítását kívánta elősegíteni. Az aktivista 90-es években kiteljesedő szerepével Bourdieu a cselekvővé válást kívánta elősegíteni, a baloldali politikai mozgalmak egyik fő támogatójaként a fennálló uralmi viszonyok és egyenlőtlenségek leleplezését tűzte ki célul.

Fáber a Bourdieu-t érő kritikák tárgyilagos ismertetése ellenére hangsúlyozza azt a véleményét, miszerint bár a determinizmus vádja nem alaptalan, a kései Bourdieu közéleti szerepvállalása nem a korábban kidolgozott elmélete kudarcát mutatja. A „két Bourdieu” összeegyeztethetősége mellett érvelők azt állítják, hogy a szociológus közéleti tevékenysége logikus és következetes meghosszabbítása a korábban kifejtett tudományos munkájának. Nem elhanyagolható szempont, hogy Bourdieu kétféle tevékenységében erős időrendiség is megjelenik. A kutató fiatalon a „cselekvéselmélet” kidolgozásával foglalkozott, érett kutatóként pedig az aktivizmusba forgatta a felhalmozott tudását és társadalmi tőkéjét.

A könyv második fejezete Bourdieu „cselekvéselméletének”, a gyakorlat elméletének kifejtésével foglalkozik. Bár Bourdieu elutasította a marxi determinista felfogást, amely szerint az osztályhelyzet meghatározza a cselekvők - bourdieu-i nyelvezetben: ágensek - cselekvési képességeit, a habituselméletében, amelyben a helyzetek cselekvési valószínüségeit írja le, mégsem tud megszabadulni attól az ellentmondástól, hogy ezek a cselekvések és reakciók az ágenseket az eredeti társadalmi pozíciójukhoz kötik. Fokozva az ellentmondást, Bourdieu kiemeli, hogy a habitus egyik legfőbb „feladata” a fennálló viszonyok konzerválása, amit az intézményrendszerek - kiemelt példaként az oktatási rendszert említi - még inkább 
felerösítenek. Az ágensek által fel nem ismert uralmi viszonyok és az így kialakuló tehetetlenség eredménye a rendszerek reprodukciója, megszilárdulása. Bourdieu e kettősséget kívánja a későbbiekben közéleti tevékenységével feloldani: elsősorban kutatási eredményeire támaszkodva leplezi le a társadalom egésze előtt az őket is érintő egyenlőtlenségeket, másrészt az elméletében is megjelenő „szabad akarat” fontosságát hangsúlyozza. A determinizmus vádját e kései tevékenységével kívánja megcáfolni azáltal, hogy bemutatja, miként mobilizálhatók az ágensek, a mozgósított „szabad akarat” milyen módon csatornázható cselekvésekbe.

A könyv rendszeresen hivatkozik Luc Boltanskira és a pragmatikus szociológia elméletére. Fáber egy egész fejezetben ismerteti az egykori Bourdieu-tanítvány korai tevékenységét, majd a 80-as években a mesterétől elforduló szociológus írásait. Boltanski a bourdieu-i elmélet legkritikusabb pontjait kívánta megválaszolni, konkrétan a mindennapi cselekvő és tudós közötti reflexitásbéli különbségekre, a cselekvések determináltságára, valamint az élet minden területét átszövő uralmi helyzetekre reagált. A Boltanski által megalkotott, önmagát konkurens elméletként aposztrofáló teória középpontjában a vitahelyzetek megfigyelése áll, a citék Thévenot-val közösen alkotott rendszere az újdonság erejével hatott a tudóstársadalomra. A szerzőpáros megkérdőjelezi a cselekvők tehetetlenségét, a kérdést a vitahelyzetekben megnyilvánuló partikuláris látásmódon való felülemelkedéssel oldották fel. A bourdieu-i elméletben állandó és mindent átszövő uralmi helyzeteket az egymással együttmüködő és konfliktuskezelő cselekvők képével ütköztették, a tudós és a cselekvő közötti aszimmetriát a képzett és olvasott szakemberek jelenlétével ellensúlyozták. Míg Bourdieu elméletével kapcsolatban leggyakrabban a determinizmus vádja merül fel kritikaként - ami arra utal, hogy a habitusok konzerválják, újratermelik az egyenlőtlen viszonyokat -, addig Boltanskiék arra a megállapításra jutottak, hogy amennyiben a cselekvéseket nem hatja át a bizonytalanság valamely foka, úgy a cselekvő nem is kerülhet döntési helyzetekbe, s ezáltal a cselekvés sem valósulhat meg - tehát döntési helyzetek nem jöhetnének létre eleve determinált szituációkban. Véleményük szerint a determinizmus magát a cselekvést teszi lehetetlenné. Boltanski az egykori mestere mondhatni legnagyobb kritikusává vált, szilárdabb alapokon álló társadalomelmélettel kívánta megdönteni a bourdieu-i „cselekvéselméletet”. Pályafutása későbbi szakaszában ez a heves ellentét enyhült, Boltanski felismerte, hogy a cselekvők kritikai tevékenységének elemzése nem ad teljes körü társadalomkritikát.

Fáber reagál Bourdieu munkásságának fő kérdésére, miszerint lehetséges-e a társadalmi folyamatokba történő beavatkozás, és amennyiben igen, kinek a feladata ez. Bourdieu e tekintetben egyértelmű választ ad: a szociológust látja az egyetlen lehetséges szereplőnek, aki képes megvilágítani az ágensek számára az elnyomottságukat. A „cselekvéselmélete” gyakorlatba történő átültetése során a háttérbe kívánja szorítani a strukturalizmusból és marxizmusból átörökített elemeket, és a „cselekvők” bizonyos fokú szabadságát hangsúlyozza az ágensek tehetetlenségével szemben.

A Bourdieu által bejárt életút meghatározta tudományos tevékenységét, az őt foglalkoztató kérdéseket. A társadalom- és humán tudományok képviselői a tudományos mezőben kitüntetett szerepet foglalnak el: szakmai tevékenységük alatt a saját életükből merített problémákból, kérdésekből táplálkoznak, így a tudományos karrier egyfajta sajátos önismereti folyamat is. Bourdieu e tekintetben is az élen járt, az általa megvalósított intragenerációs mobilitás, az alsó középosztályból történő felemelkedése a francia akadémiai élet krémjébe adta fö kutatási kérdéseit: „cselekvéselméletében” meghatározó szerepet játszott a habitus 
fogalmának kifejtése, az emberi viselkedések valószínüségét meghatározó fogalom megalkotása. Lenyügözte az a megfigyelése, miszerint az egyéni tevékenységek külső koordináció nélkül képesek összehangolódni. Azonban e kérdésben a teljes spontaneitást sem tartotta elképzelhetőnek.

A munkásságával mintegy hívószóként összefonódó fogalom a mezőelmélet. A társadalmat kisebb, szorosabb és gyengébb kapcsolatokkal összefonódó viszonyok rendszereként képzelte el. A mezők egyéni érdek- és értékrendszerüket követve jönnek létre és fejlődnek, a mezőbe való belépési küszöböt a viszonyrendszer tagjai és a mező kritériumai határozzák meg. Bourdieu életművében kitüntetett szerepet töltött be a tudományos mező feltárása, a francia tudós közösség kapcsolatainak, dinamikájának bemutatása. Munkássága e szeletével véleményem szerint egy sajátos önismereti folyamatot is bejárt: a családjától örökölt habitusának tudatos háttérbe szorításával találta meg a helyét az akadémiai szférában, azonban az új szerepét sem tudta teljes mértékben magáévá tenni. A mező feltárása önmaga számára is bemutatta a mező határait, a mező müködésének előnyös és káros oldalait.

Fáber az egész mü során vezérfonalként használja a Bourdieu-t ért kritikák leghangsúlyosabbikát, a determinizmus vádját, s többek között e mítoszt is meg kívánja dönteni. A cselekvővé válást és változtatásra való készséget véleményem szerint mi sem mutatja jobban, mint Bourdieu személyes életútja, ahol ő maga példázza a habitus formálhatóságának lehetőségét. E kérdéshez kapcsolódik a szociológus élete végét meghatározó közéleti szerepvállalása is. Célként azt tűzte ki, hogy az általa feltárt egyenlőtlenségi és hierarchikus viszonyokat leleplezze a habitusuk miatt kiszolgáltatott helyzetben ragadt társadalmi osztályok számára.

Fáber munkája hiánypótló, egyszerre építi és rombolja a Bourdieu-mítoszt. A könyv olyan összefoglaló írás, amely segíthet tájékozódni a francia szociológus összetett munkásságában. Fáber érthető és konzekvens módon építi egymásra a szerző életszakaszainak és az általuk felvetett tudományos kérdéseknek a sorát, logikus fonallá füzve össze Bourdieu írásait. A könyv nem csupán a tudóst, hanem Bourdieu-t mint magánembert is megjeleníti előttünk, mivel bemutatja a tudományos kérdéseinek egymásra épülését, bepillantást enged habitusának formálódásába is.

Fáber munkája hiánypótló. Nem kis vállalkozás egy ennyire összetett és nagy hatással bíró munkásság kritikai, mégis érthető összefoglalása. A magyar szociológiai képzések központi és egyik legelrettentőbb eleme Bourdieu írásainak megismerése, miközben a francia szociológust feltehetőleg nem az általa alkotott elmélet tartalma teszi az ifjú hallgatók egyik rémálmává, sokkal inkább a müveiben használt összetett nyelvezet.

A tudományterületek elkerülhetetlenül rendelkeznek sajátos nyelvezettel és szókincscsel, amelyet csak a beavatottak, a mező tagjai ismernek és használnak rendeltetésszerüen. A szociológia és más társadalomtudományok e tekintetben sajátos szerepet töltenek be: a feltárt területek és a szociológust foglalkoztató kérdések olyanok, amelyek az emberek jelentős részét érdeklik, a szociológia tárgya maga az ember. Ezáltal nagyon nehéz éles határvonalat húzni a tudomány köré, a szociológiai mező határai kevésbé élesek, mint más, akár természettudományos mezőké. A társadalomtudósok természetes reakciója - saját határaik védelme érdekében - az, hogy egy olyan sokrétü tudományosságot alkotnak meg, melynek eleme például az összetett nyelvezet vagy a sajátos, a társadalom számára szinte érthetetlen és bonyolult empirikus módszertan kifejlesztése, amelyet tehát csak ők, a mező tagjai értenek. Bourdieu munkásságával szemben is felmerül az e beállítódással szembeni kritika lehetősége, írásainak nehézkes mondatszerkezetei elrettentik az érdeklődő laikusokat. 
Védelmére szóljon, hogy életének utolsó szakaszában pontosan e határok és falak ledöntésén munkálkodott, közéleti szerepvállalásával, valamint a Liber Raisons d’Agir kiadó könnyedebb nyelvezetben megírt ismeretterjesztő könyvsorozatával.

Fáber munkája hiánypótló írás a magyar piacon. Nem csupán Pierre Bourdieu munkásságának bemutatásával alkotott maradandót a magyar szociológus a társadalomtudósok és a közéleti kérdések iránt érdeklődők számára, hanem a francia szociológus életpályájának boncolgatásával olyan kérdéseket is körbejár, melyek már szinte minden - pályája bármely szakaszában járó - társadalomtudós fejében megfogalmazódtak. A szociológusok tevékenységük során nap mint nap szembesülnek a társadalmi igazságtalanság számos aspektusával, a tenni akarás vágya és az egyenlőtlenségek újból és újból megmutatkozó rétegei sok tudóst választás elé állítanak: maradjanak-e meg a tiszta tudományos mezőben (már amennyire e mező független tud maradni a gazdasági, piaci és egyéb érdekcsoportok tevékenységétől), vagy pedig tudásukat, a felismert egyenlőtlenségekből fakadó elégedetlenségüket csatornázzák-e át közéleti tevékenységbe, társadalmi aktivizmusba.

Pierre Bourdieu pontosan e kérdések mentén lavírozva alkotott, életének utolsó szakaszában pedig a közéleti tevékenységre és az egyenlőtlenségek leleplezésére fókuszáló „fordulatával” a tudományos ismereteit próbálta közérthető és mégis tartalmas módon szélesebb társadalmi rétegek elé tárni. Bourdieu a tevékenységével - ahogy Fáber is érvel - nem fordult el a tudományos világtól és vált a politikai szféra, mező szereplőjévé. Sokkal inkább a cselekvés- és habituselméletét próbálta gyakorlattá formálni. E tevékenysége azonban rámutatott az elmélet hiányos, ki nem fejtett pontjaira is: az általa feltételezett nem reflexív egyéni cselekvő és tudós közötti óriási szakadék kérdésére. Érdekes eljátszani azzal a gondolattal, mivé nőtte volna ki magát Bourdieu munkássága, ha alkalma adódik mélységében reflektálni a közéleti tevékenysége alatt tapasztaltakra.

\section{Bartha Diána}

Szociológus, Eötvös Loránd Tudományegyetem (Budapest), junior kutató 


\title{
Az Információs Társadalom 2020/3-as számának tartalma
}

\author{
BÓDI ZOLTÁN \\ Digitális identitás - nyelvi identitás - digitális kommunikációs kör- \\ nyezet \\ JULESZ MÁTÉ \\ A telemedicina és a COVID-19-világjárvány
}

KREK NORBERT

Egy letünt műfaj? A fantasy izometrikus szerepjátékok eltűnésének lehetséges okai a 2000-es évek elején

SASVÁRI PÉTER, VARANNAI ISTVÁN, URBANOVICS ANNA Interaktivitás növelése a tanórákon - A gamifikáció eszközeiről alkotott kép egyetemi hallgatók körében

VAJDA KINGA

Az idős generáció és az infokommunikáció kapcsolata az idősek nappali ellátásában - Szociális szolgáltatásfejlesztési és prevenciós perspektívák egy hazai kutatás tükrében

\section{https://inftars.infonia.hu/}

